\title{
Towards the Internationalisation Process of Lithuanian Universities
}

\section{Jolita Greblikaitè}

Aleksandras Stulginskis University, Universiteto str. 10, LT-53361, Kaunas, Lithuania

\section{Jurgita Barynienè, Živilè Paužaitè}

Kaunas University of Technology, A. Mickevičiaus st. 37, LT-44244, Kaunas, Lithuania

\section{$\Gamma$ Crosef http://dx.doi.org/10.5755/j01.eis.0.9.12797}

Under the pressure of globalisation and information technologies' revolution nowadays world is characterized as fast changing and unpredictable. In such environment organisations cannot act separately in local markets. Consequently the internationalisation becomes as one of the vital preconditions for surviving in nowadays world.

This paper focuses primarily on the internationalisation process which is complex and multifaceted. For this reason the authors present the deep analysis on internationalisation concept and introduce it as a process which is developed in regional, national and local - organisational levels.

Higher education institutions and especially universities face the challenge of internationalisation as well. Universities which prepare graduates for nowadays labour market should react to ongoing changes and make their strategies orientated towards internationalisation. Universities separately implement internationalisation in their institutions according to their own institutional priorities. However it is noticed that the fragmentation of internationalisation process makes a negative impact on universities activities and competitiveness. Consequently the universities should think about their internationalisation strategies achieving their strategic goals. Scientific problem of the article is based on fostering competitiveness of Lithuanian universities in the EU or even global market, where internationalisation appears as one of main preconditions to achieve it.

In developing these insights the paper aims to reveal the peculiarities of internationalisation process in Lithuanian universities. To achieve this aim three tasks were solved: to analyse the development of internationalisation concept; to analyse political and strategic guidelines of internationalisation of Lithuanian universities; to highlight the peculiarities of internationalisation implementation in Lithuanian universities.

The paper presents qualitative research methods such as: analysis of Lithuanian and international scientific papers, analysis of the EU and Lithuanian documents, statistical comparative and explanatory analysis and interpretation.

The results of the article: there was presented the common concept of internationalisation; there were analysed political and strategic guidelines of internationalisation of Lithuanian universities; there were highlighted main peculiarities of internationalisation's implementation in Lithuanian universities.

KEYWORDS: Internationalisation, internationalisation concept, internationalisation process, internationalisation of Lithuanian universities.

\section{Abstract}

Towards the Internationalisation

Process of

Lithuanian

Universities

Submitted 04/2015

Accepted for publication 07/2015

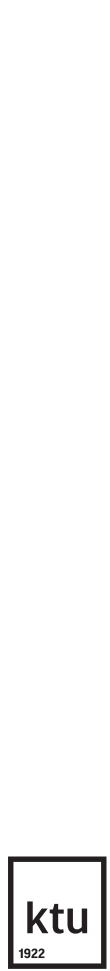

European Integration Studies No. 9 / 2015 pp. 73-85

DOI 10.5755/j01.eis.0.9.12797 (c) Kaunas University of Technology 
During last decades the process of internationalisation becomes one of the most important issues in scientific and public discussions. Private and public organisations deal with one and the same question, how to become more internationalised and use this as the competitive advantage for the improvement of situation in volatile market.

Institutions of higher education also treat the internationalisation as the vitally important process for their existence. This issue is broadly discussed in scientific literature (Knight, J., 1997, 2004, 2005, 2008; Teichler, U., 2009; Kreber, C., 2009; Kehm, B.M., 2011; De Wit, H., 2002, 2010, 2011; Maringe, F., 2010; Fosket, N., 2010; Martin, M., 2011, Bulajeva, T., 2005, 2013).

Furthermore internatiolisation as a process experiences changes and modifications. According to Wächter B. (2004) the understanding of internationalisation recently becomes widened. It includes not only the mobility of students and scholars, but deals with joint international efforts related to structural and regulatory issues of higher education systems as such. Universities recently recognise internationalisation not as a final goal, but as a process of development, a way of new thinking and understanding. Internationalisation appears as a new tool for competitiveness in a global market.

All higher education institutions (public or private) without exceptions act in global area and think about the strategies and actions of internationalisation. According to the OECD, during 2000 2011, the number of international students extremely increased. European Commission declares that the number of students abroad is going to quadruple till 2030. Lithuania has an aim to reach 10 percent of foreign students from total number of students in 2020.

Internationalisation approach is highlighted in political level as the strategic trends of higher education (HE) institutions. International Association of Universities (IAU), European Universities Association (EUA) as well as European Commission (EC) embody the significance of internationalisation which strongly relates with the priorities of Europa 2020, in which education is seen as the backbone of European economic development.

A lot of efforts towards smooth internationalisation process are made in national level as well. Lithuanian universities deal with internationalisation processes in parallel with European Commissions initiated Bologna process, already from 1999, however the necessity to face internationalisation as a need for broader and more strategic perspectives appeared only later, from 2006. Lithuanian universities still face a challenge of new thinking, understanding and presenting their self as a part of internationalisation process. Here the scientific problem is raised for deeper analysis: fostering competitiveness of Lithuanian universities in the EU or even global market, where internationalisation appears as one of main preconditions to achieve it. The main aim of this paper is to reveal the peculiarities of internationalisation process in Lithuanian universities in the context. The object of the paper is internationalisation of Lithuanian universities.

To achieve the aim three tasks were solved:

_ to analyse the development of concept of internationalisation identifying main rationales of universities for internationalisation;

_ to analyse political and strategic guidelines of internationalisation of Lithuanian universities; _ to highlight the peculiarities of internationalisation implementation in Lithuanian universities.

Novelty of the paper: scientific generalisation of internationalisation process of Lithuanian universities is still missing. In this matter made analysis in this paper creates an added value for future scientific insights and recommendations regarding internationalisation process in Lithuanian universities.

The research is based qualitative research methods such as analysis of Lithuanian and international scientific papers, analysis of the EU and Lithuanian documents, statistical comparative and explanatory analysis and interpretation. 
In scientific literature there is emphasized that the importance of internationalisation process erected under the pressure of globalisation (Altbach, P. G, Reisberg, L., Rumbley, L. R., 2009; Altbach, P. G., 2006; Foskett, N., Maringe, F., 2010). Nevertheless, it could be found some confusion in scientific literature regarding these two concepts (Altbach, P. G., 2006). Globalisation nowadays is used in different context and become one of buzzwords. Despite of this, globalisation influenced and accelerated many processes in nowadays societies. Internationalisation is not the exception and could be treated as the contemporary respond to the globalisation.

Analysing the factors which influenced the internationalisation process the technological development should be mentioned as well. Rapid development of information and communication technologies has led the erection of new possibilities in education field, for example distance learning, MOOCs and etc. In practical and strategic level the possibilities of internationalisation at home broadly discussed. Internationalisation at home involves the tools which provide the opportunity to be international for non - mobile students. It involves the curriculum, didactic methods which are orientated on internationalisation.

However internationalisation is not new issue in higher education agendas. According to the university fundamental mission, this institution is orientated to internationalisation. For example, the mobility of students and professors is noticed even in the Middle Ages. Welch, A. R., Denman, B. D (1997) highlight that in the Middle Ages Greek scientists visited other countries. Despite of this, scientists agree that nowadays internationalisation gathers new pace and trends.

The literature on internationalisation embodies the complexity of this concept. The variety of internationalisation concepts are presented in Table 1.

De Witt, H. (2015) extended earlier understanding of internationalization process. According to this, higher education institutions should treat themselves as global actors and think globally. Such strategic thinking should be implemented in all universities actions (from research and studies to management processes).

Knight, J. (1997) made in depth analysis of internationalisation concept and set four different approaches, such as:

_ activity approach (the scope of activities which describe the internationalisation: curriculum, student/faculty exchange, international students);

_ competency approach (knowledge, skills, attitudes and values of students, staff, administration);

\begin{tabular}{l|l}
\hline \multicolumn{1}{c|}{ Definition } & \multicolumn{1}{c}{ Authors } \\
\hline $\begin{array}{l}\text { A broad scope of international activities, international relations and } \\
\text { cooperation, international study programmes and research initiatives }\end{array}$ & Knight, 2004 \\
\hline $\begin{array}{l}\text { Integration and infusion of an international dimensionas a central part of a } \\
\text { university's programs }\end{array}$ & $\begin{array}{l}\text { Zolfaghari, } \\
\text { Sabran, Zolfaghari (2009) }\end{array}$ \\
\hline $\begin{array}{l}\text { The process of integrating the institution and its key stakeholders - its } \\
\text { students, faculty, staff - into a globalizing world }\end{array}$ & Hawawini, G. (2011) \\
$\begin{array}{l}\text { The intentional process of integrating an international, intercultural or global } \\
\text { dimension into the purpose, functions and delivery of post-secondary education, } \\
\text { in order to enhance the quality of education and research for all students and } \\
\text { staff, and to make a meaningful contribution to society. }\end{array}$ & De Wit, H. (2015) \\
\hline
\end{tabular}

- ethos approach (culture, climate which stimulates intercultural initiatives);

- process approach (incorporation of intercultural dimension in all activities (teaching, research and etc.)

\section{Development of Internatio- nalisation Concept}

Table1

The Internationalisation Concept 
Reid, S., et al. (2010) have acknowledged seven approaches of internationalisation which include ethos (culture of institutions with atmosphere which is friendly to internationalisation); infusion (students, staff participation); mobility (curricula internationalisation), overseas campus (new branches of universities in other countries); internationalisation through content (cultural elements incorporated in courses); internationalisation through social events (mix of local and foreign students using platform of events); competency (especially intercultural competency including knowledge, skills, abilities, values).

These conceptualisations prove the complexity and contextualisation of internationalisation process. Universities choose different ways of internationalisation. Bartell, M. (2003) argues that it depends on structure of university, strategic approaches, and organisational culture. In the end of the $20^{\text {th }}$ century, universities focused more on activity approach. However now the process approach is leading and internationalisation is understood as the systemic process.

Why the internationalisation is so important for universities?

According to the analysis of literature, four important rationales of internationalisation could be identified. These rationales are presented in Table 2.

In should be noticed that these rationales are strongly interconnected (Agoston, S., Dima, A. M., 2012). Rationales could be different according to the country/regions peculiarities (De Witt, H., 2010). In particular, rationales depend on institution's strategy, vision, mission, main priorities, human resources, financial capital.

The internationalisation brings one of important goals in knowledge based economies and societies - provide the possibility to participate in global networks, to create, use and disseminate the knowledge which is essential for economic development.

Today universities should rethink their strategies of internationalisation. NAFSA (2012) identified several major shifts for higher education institutions regarding the internationalisation:

_ to create the alliances between higher education institutions. These alliances based on collaboration could help to successfully compete; _ to seek for world talents which could be en- rolled in education;

- to identify the strategic partners and strengthen this partnership in order to achieve economic, geopolitical aims;

\begin{tabular}{|c|c|c|c|}
\hline \multirow{5}{*}{$\begin{array}{r}\text { Table } 2 \\
\text { Rationales of } \\
\text { Internationalisation }\end{array}$} & Rationale & Description & Authors \\
\hline & $\begin{array}{l}\text { Political } \\
\text { rationale }\end{array}$ & $\begin{array}{l}\text { Intensification of national identity, } \\
\text { strengthening the mutual relations } \\
\text { between countries. }\end{array}$ & $\begin{array}{l}\text { Knight, J. (1997), de Wit, H. (2002), Altbach, P. G, } \\
\text { Knight, J. (2007); Baron, B. (1993); Amaral, A., } \\
\text { Tavares, O., Cardoso, S., Sin, C. (2015) }\end{array}$ \\
\hline & $\begin{array}{l}\text { Economic } \\
\text { rationale }\end{array}$ & $\begin{array}{l}\text { The match between graduates } \\
\text { competencies and labour market } \\
\text { which stimulates economic growth } \\
\text { and cohesion in societies }\end{array}$ & $\begin{array}{l}\text { Knight, J. (1997), de Wit, H. (2002), Altbach, P. } \\
\text { G., Knight, J. (2007), Maringe, F., Woodfield, S. } \\
\text { (2013), Amaral, A., Tavares, O., Cardoso, S., Sin, } \\
\text { C. (2015) }\end{array}$ \\
\hline & $\begin{array}{l}\text { Academic } \\
\text { rationale }\end{array}$ & $\begin{array}{l}\text { The implementation of international } \\
\text { standards in learning and research } \\
\text { process }\end{array}$ & $\begin{array}{l}\text { Knight, J. (1997), de Wit, H. (2002), Altbach, P. } \\
\text { G., Knight, J. (2007), Maringe, F., Woodfield, S. } \\
\text { (2013), Amaral, A., Tavares, O., Cardoso, S., Sin, } \\
\text { C. (2015) }\end{array}$ \\
\hline & $\begin{array}{l}\text { Cultural/ } \\
\text { social } \\
\text { rationale }\end{array}$ & $\begin{array}{l}\text { The improvement of intercultural } \\
\text { competencies. These competencies } \\
\text { are seen as main acting in nowadays } \\
\text { multicultural societies all over the } \\
\text { world. }\end{array}$ & $\begin{array}{l}\text { Knight, J. (1997), de Wit, H. (2002), Altbach, P. } \\
\text { G., Knight, J. (2007), Maringe, F., Woodfield, S. } \\
\text { (2013), Amaral, A., Tavares, O., Cardoso, S., Sin, } \\
\text { C. (2015) }\end{array}$ \\
\hline
\end{tabular}


European Commission pays big attention to internationalisation processes in EU. In order to stay competitive, European Commission decided to rethink higher education and presented new higher education strategy (Communication from the Commission to the European Parliament, the Council, the European Economic and Social Committee and the Committee of the regions), in which three important issues are highlighted (EC, 2013):

\section{Smooth mobility including students and staff. (This dimension relates with process of competencies recognition, focuses on learning outcomes.) \\ - Internationalisation of curriculum (experi-}

ence gained abroad, languages competencies, international cooperation);

_ Strategic cooperation (strategic partnerships, joined/doubled degrees), in order to trigger the internationalisation.

The internationalisation process in Europe is influenced by European Higher Education Area (EHEA) which could be treated as facilitator achieving goals of internationalisation. Erasmus + programme could be mentioned as the example of internationalisation process in Europe.

Internationalisation as a consequence of globalisation particularly affects small states (Urbanovic J, Wilkins 2013; Martin M. 2011). Integration into international markets becomes crucially important not only for business sector but also for higher education institutions to be competative. Although internationalisation was always an important aspect for universities, recently it turns into a strategic goal globally, regionally and locally. Due to this fact countries choose to implement internationalisation process by different strategies according to its focus and geographical scope. Maringe, F. (2010) identifies five broad categories of internationalisation strategies:

_ the recruitment of international students;

_ student and staff mobility;

_ international partnerships, including joint programmes of study;
_ international collaboration for research, entrepreneurship or development; _ internationalisation of the curriculum.

Fosket, N. (2010) points out that 'being international' also has quality dimensions not only geographical. Internationalization involves institutions working with individuals and organisations from other countries and ensuring that their education and research are of a standard that is recognised as being of 'international quality'. According to Urbanovic, J., Wilkins, S. (2013) at both national and institutional levels, a range of internationalisation strategies can be developed and implemented to improve the quality of higher education in small states (Table 3).

Knight, J. $(2005,2008)$ and Urbanovic, J., Wilkins, S. (2013) state that internationalisation revolves around two basic components: internationalisation at home - the actions undertaken in the institution's home context (rather curriculum-oriented) and internationalisation abroad - offshore activities. These components do not exclude one another, but are intertwined in policies and programmes (Table 4).

Internationalisation of higher education could be achieved through geographical dimension focusing on actions in different scopes: globally, regionally and nationally. As one of the examples of a regional internationalisation strategy of higher education could be considered the Bologna process. This strategy is focused on higher education in the European Union region and its partner countries. The main goal of Bologna process was a creation and implementation of European Higher Education Area by 2010. It is obvious that the Bologna process has stimulated higher education reforms in the majority of European Countries politically and practically at both national and institutional levels. It has become a tool to make common decisions as well as create long term programmes (Karveliene, R., 2014, Ubanovic, J., Wilkins, S., 2013). However, the Bologna Pro- 
Table 3

Possible strategies to improve the effectiveness of higher education internationalisation in small states (adapted according to Urbanovic, J., Wilkins, S., 2013)

Table 4

Components of internationalisation at home and abroad

\begin{tabular}{|c|c|}
\hline Establish & clear goals and strategies at both national and institutional levels \\
\hline Develop and implement & a carefully planned change management programme \\
\hline Measure and evaluate & performance after internationalisation strategies are implemented \\
\hline Allocate & adequate funds for investment and improvement \\
\hline Engage & in benchmarking with the best higher education systems and institutions globally \\
\hline Invest & $\begin{array}{l}\text { in staff development to improve understanding of internationalisation } \\
\text { goals and } \\
\text { methods } \\
\text { in training to improve the foreign-language competence of staff } \\
\text { (teaching and nonteaching) }\end{array}$ \\
\hline Establish & more international partnerships and collaborative agreements \\
\hline Achieve & economies of scale through institutional mergers \\
\hline Attract & the best international professors and students \\
\hline
\end{tabular}

\begin{tabular}{l|l}
\multicolumn{1}{c|}{$\begin{array}{c}\text { Internationalisation at home } \\
\text { Campus }\end{array}$} & $\begin{array}{c}\text { Internationalisation abroad } \\
\text { Cross-border }\end{array}$ \\
\hline Curriculum and programs & Movement of people \\
\hline Teaching/learning process & Delivery of programs \\
\hline Extracurricular activities & Mobility of providers \\
\hline Liaison with local cultural and ethnic groups & International projects \\
\hline Research and scholarly activity & \\
\hline
\end{tabular}

Source: (adapted according to Knight, J., 2005, 2008; Urbanovic, J., Wilkins, S., 2013).

the European Higher Education Area (EHEA) improves transparency between higher education systems, as well as implements tools to facilitate: recognition of degrees and academic qualifications, mobility and exchange between institutions.

Lithuanian universities are actively responding to internationalisation process from 1999, after the Lithuania has joined the Bologna process. However, small states such like Lithuania face an internationalisation as a challenge. With reference to Bulajeva, T. (2013), Markevičienè, R. (2013), Karvelienè, R. (2014) some Lithuania's documents (period of 1999-2012) that harmonise Lithuanian higher education (Programme for the Promotion of Internationalisation in Lithuanian HE 1999-2010, The development plan of the Lithuanian higher education system of 2006-2010, Regulations of National Education Strategy 2003-2012) concealed the international problem. However higher education institutions understood the importance of internationalisation and in their strategic and development documents assigned the internationalisation process to the development aims (e.g. universities strategic development plans, strategic activities plans, development strategies, etc.) (Karvelienè, R., 2014). In addition, concrete state documents indicating internationalisation development guidelines appear as well under the universities initiative from 2006 (2006 the study “The Global Practice of Promotion of Higher Education Internationalisation 
and Guidelines of its Application", 2008 the "Programme for the Promotion of Internationalisation in Higher Education, developed for 2008-2010", 2011 the Programme for the Promotion of Internationalisation in Higher Education 2011-2012, 2013 the National Action Plan for Internationalisation of Lithuanian Higher Education 2013-2016).

Made analysis of Lithuanian political and strategic initiatives based on concrete documents revealed a direct link between Bologna process and Lithuanian efforts towards internationalisation of Lithuanian universities (Table 5).

Made analysis of the EU and Lithuanian political and strategic documents revealed, that mobility factor in the Bologna Process plays an important role. It appears as a connecting aspect in internationalisation process of higher education. Documents introduced in the frame of Bologna Process are clearly focused to give mobility a boost and in this way to strengthen the internationalisation in HE regionally and nationally. As an example can be taken two the above mentioned documents (table 5): the European higher education in the world strategy (2013) and the National Action Plan for Internationalisation of Lithuanian Higher Education 2013-2016 (2013). Both documents simultaneously (regionally and nationally) pursue similar goals towards internationalisation of HE through mobility.

Starting from 1999 Lithuania has made a big progress in the process of internationalisation of HE. Made analysis revealed that universities and their initiatives made a big impact on identifying main obstacles of internationalisation of universities and presented strategic guidelines how to overcome them. With reference to this fact can be stated, that in small states such as Lithuania it is particularly important bottom up principle where universities play the main role. National strategic and political guidelines towards internationalisation of higher education should respond to the needs and recommendations of universities. Synergy between governmental and higher education institutions would create a harmonious basis for more effective implementation of internationalisation of higher education.

In 2014, Lithuania had 23 universities and 24 colleges of higher education, which together had around 200,000 student enrolments (Ministry of Education and Science, 2014). The number of students was about 151000 in 2013-2014. In the beginning of new academic year 2014-2015 the students' number was 99000 in universities and about 46000 in colleges (less more than 10 percent comparing with the previous year). As opposite, according Eurostat, the number of studying abroad Lithuanian young people is growing every year.

As in 2007 it was already stated that a lot of high quality potential students left Lithuania Government introduced some changes in higher education policy and its implementation. Most recent changes introduced include making all state institutions public entities, allowing them greater freedom in decision-making; a new funding mechanism which is tied to the student, so that funding goes where the best students choose to go; the availability of more state supported student loans and social scholarships; various strategies to increase the quantity and quality of research output; the introduction of more courses taught in languages other than Lithuanian, such as English, Russian and Polish; and the setting of a target to have international students accounting for 10\% of total higher education enrolments by 2020 (Ministry of Education and Science, 2011; Urbanovic, J., Wilkins, S., 2013, p. 6-7). Although internationalisation is an important aspect of the reform of Lithuania's higher education, the Ministry of Education and Science has identified globalisation and internationalisation as two of the greatest challenges.

Coping with new challenges Lithuanian universities are still suffering transition in terms of quality and quantity. Quality is related with overall operations at universities: study programmes, research, administration process. The management of universities becomes rather based on 


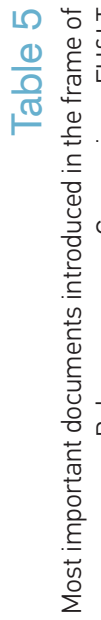

\begin{tabular}{|c|c|c|c|c|c|c|c|c|c|c|c|c|c|c|}
\hline $\begin{array}{l}\underline{\underline{L}} \\
\underline{\underline{a}}\end{array}$ & & 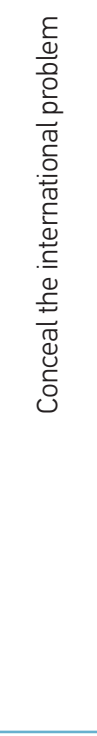 & & 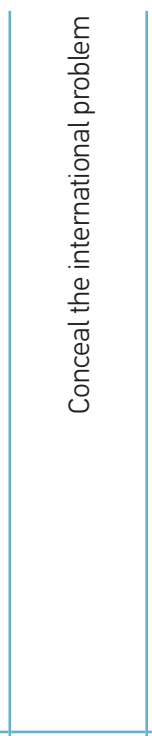 & & 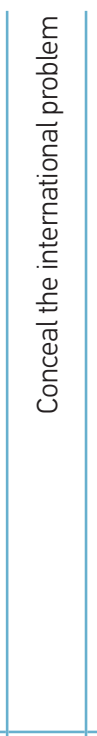 & 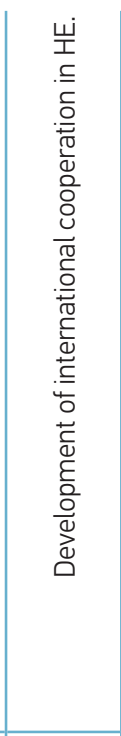 & & 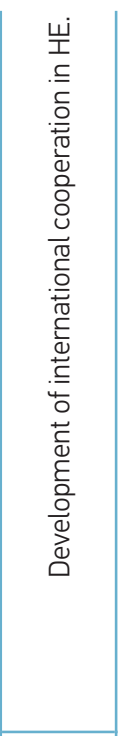 & & & 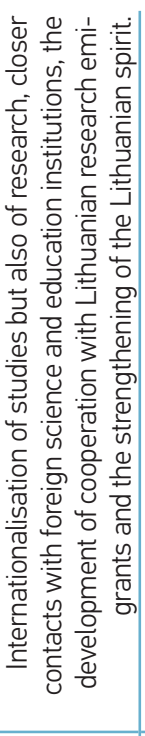 & & 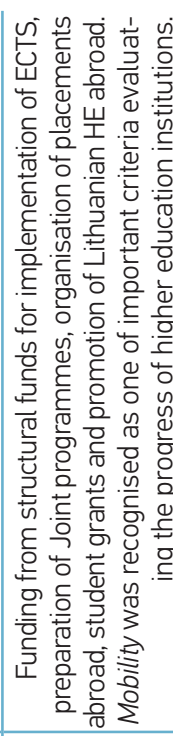 \\
\hline 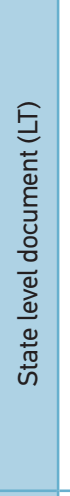 & & 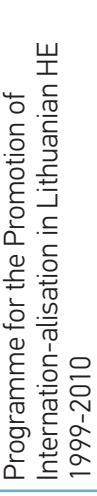 & & 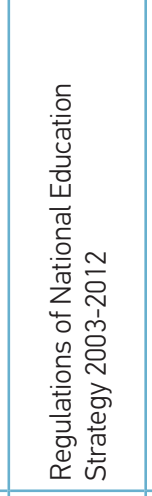 & & 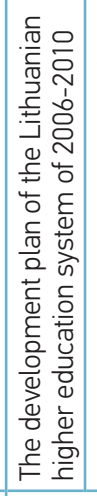 & 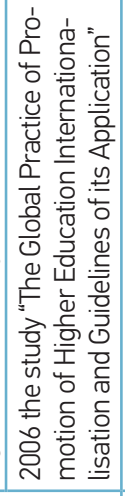 & & 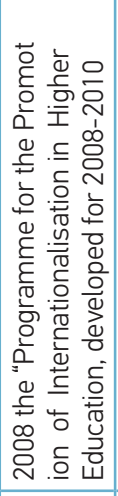 & & & 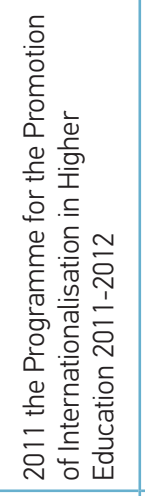 & & 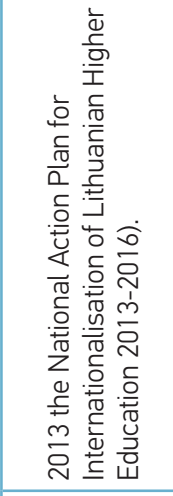 \\
\hline 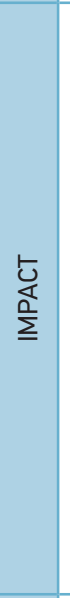 & 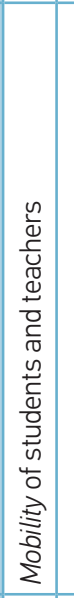 & 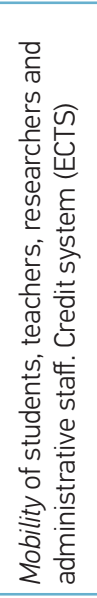 & 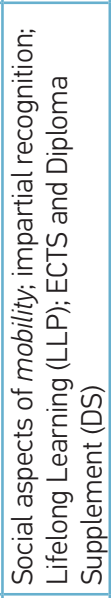 & 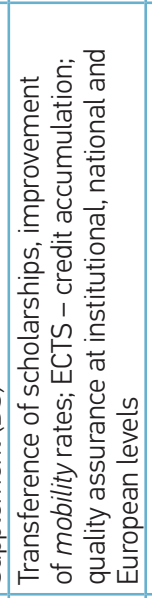 & 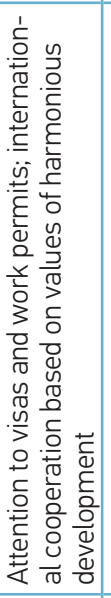 & & & 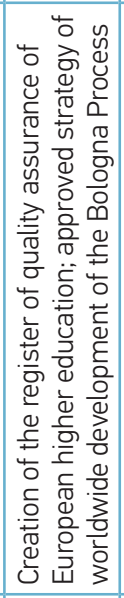 & & 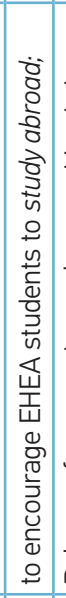 & 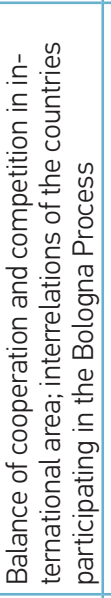 & & 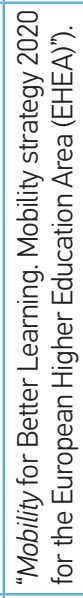 & 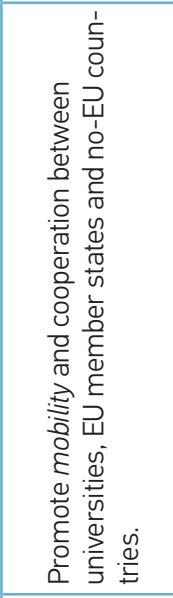 \\
\hline 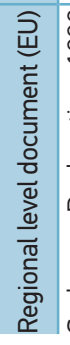 & 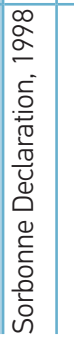 & 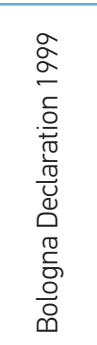 & 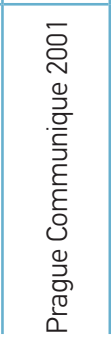 & 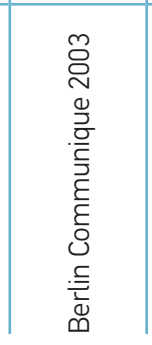 & 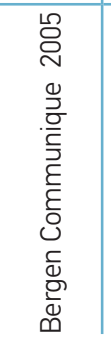 & & ¿̊․ & 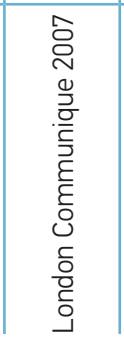 & & 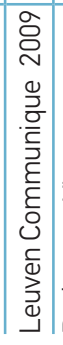 & 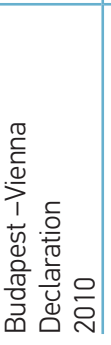 & $\overline{\bar{\nu}}$ & 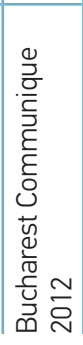 & 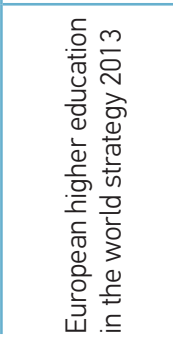 \\
\hline
\end{tabular}


achieving goal in every field of activity. Quantity is tied to the number of the universities needed in Lithuania as well as to the number of the students studying and willing to study in Lithuania. Lithuanian universities suffer two competing major trends - globalisation and regionalisation (Musial, K., 2007). Playing globally the need of internationalisation grows. The excellence of teaching and research is required playing internationally or on global scale. As the social actors universities play specific role engaging themselves in closer with the society and its needs. This role is implemented through the certain forms of professional training, partnership, consultancy, and research (Janiunaite, B., Gudaityte, D., 2007).

The synergy of combining three identities - regionalism, nationalism and internationalism - is a challenge for Lithuanian universities. Enders, J. (2004) sees internationalisation as a universal trend in higher education. Some universities have high regional trend or even local focus as their identification, for example, Siauliai University or Klaipeda University in Lithuania. Those universities serve for the region in economic and cultural terms and have their specificity in the orientation of study fields as pedagogy in Siauliai University or marine studies at Klaipeda University. Such universities are focusing their activity on their closest locality where potential students can be accessed. The focal point focusing on local community remains up to fifty kilometres radius from the institutions.

The universities based in capital of Lithuania - Vilnius - are moving towards cosmopolitism as well as implementing quality assessment for excellence. For example, Vilnius University might be well acting at supranational level, for example, in the Baltic region. Virtual and physical mobility of academics created transnational community in Lithuanian universities. The role of academics overlapped the boundaries of generating and processing knowledge and reached the mobility of academic products. Implementation of joint degree programmes can assure transnational cooperation and quality in educational process as well.

The second biggest town of Lithuania - Kaunas suffers more transitional path for universities willing to be based on internationalism and on the other hand implementing some regional functions. Kaunas University of Technology participates in regional development projects and is a strong actor for regional development in the area. The university also faces some lack of students and this is leading to thought about the one university in Kaunas region named Kaunas University integrating three or even five universities. Such changes are effecting the development of universities in two sided way. Universities are willing to make changes and strengthening their positions. From the other side universities are not sure about future perspectives and reorganisations which will influence all strategies and development trends again.

On the other hand EU enlargement and free flow of labour empowered to take the strategies of internationalisation for almost every university in Lithuania creating new types of clients (for example, Belarus, Russia, Kazakhstan, India, Pakistan, Spain, Nigeria, Ukraine and etc.) and stakeholders who became a requirement for future success. Universities are adapting their strategies for their new potential students, especially strengthening teaching in English or Russian, moving to e-teaching and e-learning. Sometimes such actions are more useful to foreign students and native students suffer inconvenience lacking knowledge of foreign languages or even might be not adjusting to multicultural groups. In these cases applied management is important as means of effective internationalisation strategy implementation. The staff of universities feel more obliged to follow Bologna process documents than feel the need of quality assessment in all university processes including internationalisation (Urbanovic, J., Wilkins, S., 2013). Even the price for foreign students is rather low at Lithuanian universities, but infrastructure is not sufficient and bureaucracy procedures are rather complex for administration.

According Urbanovic, J., and Wilkins, S., (2013), there are as much benefits as drawbacks imple- 
menting internationalisation of higher education in such rather small countries as Lithuania (see Table 6). Such positive aspects as improvement of quality, becoming more competitive, getting additional funds, acquiring intercultural competence are very important for universities and it might serve as precondition for playing on a global scale.

Despite of a lot of positive aspects internationalisation of universities in Lithuania has some doubtful areas where additional attention should be paid. Appropriate considerations should be made concerning costs of internationalisation, impact on quality of study and teaching, adequate competence identification, even some racial questions.

Developing strategies of internationalisation for concrete university should be considered according to the goals, capabilities and expected outcomes. Effectiveness of internationalisation in universities should be evaluated. Special attention should be paid for higher education policy de-

Table 6

Potential benefits and drawbacks of internationalisation in higher education in small states

Conclusions

\begin{tabular}{|c|c|}
\hline Benefits & Drawbacks \\
\hline $\begin{array}{l}\text { Increases legitimacy of higher education } \\
\text { systems and programmes }\end{array}$ & $\begin{array}{l}\text { Might follow international agendas rather than national } \\
\text { interests }\end{array}$ \\
\hline $\begin{array}{l}\text { Improves international competitiveness } \\
\text { of higher education systems and institutions }\end{array}$ & $\begin{array}{l}\text { Costs of investing in infrastructure and staff development } \\
\text { can be high/unaffordable }\end{array}$ \\
\hline \multirow{2}{*}{$\begin{array}{l}\text { Improves the quality of programmes, teaching } \\
\text { and research } \\
\text { Better prepares graduates for employment in } \\
\text { the global labour market }\end{array}$} & $\begin{array}{l}\text { Internationalisation is often accompanied with some } \\
\text { momentum demand, narrowing access to higher }\end{array}$ \\
\hline & Quality might fall if international students lack language \\
\hline \multirow{2}{*}{$\begin{array}{l}\text { Provides a means to increase higher education } \\
\text { capacity }\end{array}$} & \\
\hline & ficient demand for \\
\hline $\begin{array}{l}\text { International students provide institutions and } \\
\text { nations with a new source of revenue and } \\
\text { experience }\end{array}$ & $\begin{array}{l}\text { internationalised programmes } \\
\text { Inappropriate for domestic students who do not need } \\
\text { international competencies }\end{array}$ \\
\hline \multirow{2}{*}{$\begin{array}{l}\text { Partnerships and international collaboration } \\
\text { enable participation in large-scale high quality } \\
\text { research }\end{array}$} & $\begin{array}{l}\text { Low foreign language competence among faculty and } \\
\text { students reduces quality }\end{array}$ \\
\hline & Encourages more staff members and students to join \\
\hline \multirow{2}{*}{$\begin{array}{l}\text { Promotes cultural integration and } \\
\text { understanding - develops intercultural } \\
\text { competence }\end{array}$} & \\
\hline & $\begin{array}{l}\text { Might incite increased nationalism and racism among } \\
\text { domestic population }\end{array}$ \\
\hline
\end{tabular}

Source: (adapted according Urbanovic, J., Wilkins, S., 2013).

velopment in Lithuania because of which direct influence is suffered in universities. State support in managing difficulties is sufficient and is necessary in such countries as Lithuania encountering economic and social problems and still challenging transition and strong competition in higher education as well. It seems that internationalisation is unavoidable, but the level of it might differ combining with some national and regional strategies of universities.

1

According to the made analysis the internationalisation of $\mathrm{HE}$ is a nowadays topicality and a complex and long lasting process integrating international, intercultural and global aspects. Internationalisation concept has various interpretations based on different approaches and rationales. But the essence of it remains that internationalisation is something important to understand widely and deeply as well as to implement correctly in universities for their better position in global market.

2 Since 1999 a big progress has been $\angle$ achieved in the process of internationalisation of HE regionally in the European Union 
and nationally - taking into account the case of Lithuania. Strategic documents of the European Union and Lithuania have revealed main problems of internationalisation of $\mathrm{HE}$ as well as foreseen future guidelines for its implementation. Furthermore internalisation was recognised by Lithuanian universities as a necessity for new thinking, understanding and representing their self as a competitive part of a global market.

3 In depth analysis of the EU's and Lithua3 nian documents has revealed that mobility appears as a connecting component of internationalisation of HE. Successful implementation of mobility could give internationalisation of $\mathrm{HE}$ a boost and furthermore it could accelerate the process of internationalisation.

The European Union in the regional level and the European Union member states in their national level create a management of internationalisation process of $\mathrm{HE}$ from the strategic point of view. Consequently recently appears a big demand for institutional internationalisation strategies, which would correspond to national and institutional needs as well as priorities.

5 The economic and social situation in EU $\checkmark$ and Lithuania fostered various changes in universities. Playing internationally became necessity, not only fashion. Lithuanian universities struggle three different and related paths of regionalism, nationalism, and internationalism.

6 For each Lithuanian university the strategy of internationalisation should be developed adapting to its uniqueness and main aims. But it should me mentioned that mostly common is regionalism versus internationalism or something in between, which is challenging and especially depends on implementation quality and effective management.
The Order of Minister of Education and Science of the Republic of Lithuania (2013). Action Plan of Promotion of Higher Education Internationalisation in 2013 - 2016. No. V- 878.

Agoston, S., Dima, A. M., (2012). Trends and strategies within the Process of Academic Internationalisation. Management \& Marketing Challenges for the Knowledge Society, Vol. 7, no.1, 43-56.

Altbach, P. G. (2006). Globalisation and the university: Realities in an unequal world. Tertiary Education and Management, Vol. 10, 3-25. http://dx.doi. org/10.1080/13583883.2004.9967114

Altbach P.G. and Forest J. J. F.(Eds.), 2006. International handbook of higher education. Dordrecht, the Netherlands: Springer, Vol I, 121-140. http:// dx.doi.org/10.1007/978-1-4020-4012-2_8

Altbach, P. G., Knight, J. (2007). The internationalisation of higher education: Motivations and realities. Journal of studies in international education, 11(3-4), 290-305. http://dx.doi. org/10.1177/1028315307303542

Altbach, P. G., Reisberg, L., Rumbley, L. E. (2009). Trends in global higher education: Tracking an academic revolution. Paris: UNESCO. Paris. Retrieved March 5, 2015, from http://www.uis.unesco.org/ Library/Documents/trends-global-higher-education-2009-world-conference-en.pdf
Amaral, A., Tavares, O., Cardoso, S., Sin, C. (2015). Shifting Institutional Boundaries through Cross-Border Higher Education. Journal of Studies in International Education, 1028315315587108. http://dx.doi.org/10.1177/1028315315587108

Baron, B. (1993). The Politics of Academic Mobility in Western Europe. Higher Education Policy, 6(3), 50-54. http://dx.doi.org/10.1057/hep.1993.40

Bartell, M. (2003). Internationalisation of Universities: A university culture based frame work. Higher Education, 45, 43-70. http://dx.doi. org/10.1023/A:1021225514599

Bucharest Communique (2012). Retrieved from: http://www.ehea.info/Uploads/\%281\%29/Bucharest\%20Communique \%202012\%281\%29.pdf

Bulajeva, T. (2005). Aukštojo mokslo internacionalizavimas globalizacijos sąlygomis. Acta Pedagogica Vilnensia, No 15, 179-187.

Bulajeva, T. (2013). Tarptautiškumo ir politikos iššūkiai Lietuvos aukštajam mokslui: konkurencija vs bendradarbiavimas", Acta Paedagogica Vilnensia, No 30, 104-133.

De Wit, H. (2002). Internationalisation of Higher Education in the United States of America and Europe. A Historical Comparative and Conceptual Analysis. Center for International Higher Education, Boston College Massachusetts, $270 \mathrm{p}$.

\section{References}


De Wit, H. (2010). Internationalisation of Higher Education in Europe and its assessment, trends and issues. Nederlands-Vlaamse Accreditatieorganisatie, $28 \mathrm{p}$.

De Wit, H. (2011). Misconception on internationalization of higher education. Public lecture in Amsterdam, April 6. Retrieved from Internet: http://intranet.umanitoba.ca/academic_support/catl/media/Misconceptions_on_internationalization_of_HE.pdf

De Wit, H. (2015) Quality Assurance and Internationalization. Trends, challenges and opportunities INQAAHE conference, Chicago, U.S., 30 p.

EC (2013). European higher education in the world. COM (2013) 499 final.

Enders, J. (2004). Higher education, internationalisation, and the nation-state: recent developments and challenges to governance theory. Higher education, 47, 361-382. http://dx.doi.org/10.1023/ B:HIGH.0000016461.98676.30

EUA (2013). Internationalisation European Higher Education: European policies, institutional strategies and EUA support.

Foskett, N., Maringe, F. (2010). Globalisation and Internationalisation in Higher Education: Theoretical, Strategic and Management. Bloomsbury Academic, 2010-11-04, $324 \mathrm{p}$.

Foskett, N.,(2010). Global Markets, National Challenges, Local Strategies: The Strategic Challenge of Internationalization in Maringe, F., and Foskett, N. (eds.) Globalization and Internationalization in Higher Education, London: Continuum, 35-50.

Greblikaite J., Baryniene J., Paužaitè Ž., Rauleckas R., Čeponienè L. (2014). Internationalisation of Lithuanian Universities and Its Integral Management, International Journal of Business \& Economic Strategy (IJBES), International Conference on Innovation in Business, Economics \& Marketing Research (IBEM'14), Vol.2, 6 p.

Hawawini, G. (2011) The internationalization of Higher education Institutions: A critical review and a Radical Proposal, 47 p.

IAU (2014). 4th Global Survey. Internationalisation of Higher Education. Growing expectations, fundamental values.

Janiunaite, B., Gudaityte, D. (2007). Higher education as an agent of social innovation. Higher education and national development. Universities and societies in transition. Routledge: Oxon, 215-226.

Kehm, B. (2011). Research on Internationalisation in Higher Education. Uluslararas Yükseköretim
Kongresi: Yeni Yönelifler ve Sorunlar (UYK-2011) 27-29 May 2011, Istanbul, 231-239.

Knight, J. (2004). Internationalisation Remodeled: Definitions, Approaches, and Rationales. Journal of Studies in International Education, Vol. 8, No. 1, 5-31. http://dx.doi.org/10.1177/1028315303260832

Knight, J. (1997). Internationalisation of higher education: A conceptual framework. In J. Knight, De Wit (Eds) Internationalisation of higher education in Asia and Pacific Countries. Amsterdam: European Association of International Higher Education.

Knight, J. (2005). An Internationalization Model: Responding to New Realities and Challenges, Higher Education in Latin America: The International Dimension, World Bank, ISBN: 978-0-82136209-9, 1-39.

Knight, J. (2008). Higher education in turmoil: The changing world of internationalization. Rotterdam: Sense Publishers. Education Library: LB2322.2 .K55.

Knight, J., (1994). Internationalisation: Elements and checkpoints. Canadian Bureau for International Education Research, 7, Toronto, 1-15.

Kreber, C. (2009). Different perspectives on internationalisation in higher education. Internationalising the Curriculum in Higher Education, Volume 2009, Issue 118, 1-14.

Maringe, F. (2010). The Meanings of Globalisation and Internationalization in HE: Findings from a World Survey', in Maringe, F., and Foskett, N. (eds.) Globalization and Internationalization in Higher Education, London: Continuum, 17-34.

Maringe, F., Woodfield, S. (2013). Contemporary issues on the internationalisation of higher education: critical and comparative perspectives. Compare: A Journal of Comparative and International Education, 43(1), 1-8. http://dx.doi.org/10.1080/0 3057925.2013.746545

Martin, M. (2011). Meeting social demand for quantity and quality', in M. Martin and M. Bray (eds.) Tertiary education in small states: Planning in the context of globalization, Paris: UNESCO, 73-99.

Musial, K. (2007). Regional Universities in the Baltic Sea region: higher education and regional development. Higher education and national development. Universities and societies in transition. Routledge: Oxon, 120-132.

NAFSA (2012). Retrieved from: http://www.nafsa. org/Explore_International_Education/Trends/TI/ Higher_Education_Internationalisation__Seeking_a_New_Balance_of_Values/. 
Regulations of National Education Strategy 20032012 (2003) Retrieved from: https://www.smm.lt/ uploads/documents/Lithuanian\%20Education\%2 OStrategy\%202003-2012.pdf

Reid S., Stadler S., Spencer-Oatey H., Ewington N. (2010). Internationalisation in the UK Higher Education Sector: A Competency-based Approach. Published by The Centre for Applied Linguistics, University of Warwic, p. 32. Retrieved from: http:// www2.warwick.ac.uk/fac/soc/al/research/papers/internationalisation_in_the_uk.pdf

Teichler, U. (2009) Internationalisation of higher education: European experiences. Asia Pacific Education Review, March, Volume 10, Issue 1, 93-106. http://dx.doi.org/10.1007/s12564-009-9002-7

The Bologna Declaration, (1999) Joint declaration of the European Ministers of Education. Retrieved from: http://www.magnacharta.org/resources/ files/BOLOGNA_DECLARATION.pdf

Urbanovič, J.,Wilkins, S. (2013). Internationalisation as a Strategy to Improve the Quality of Higher Education in Small States: Stakeholder Perspectives in Lithuania. Higher Education Policy, 26(3), 373-396. http://dx.doi.org/10.1057/hep.2013.6

Wächter B. (ed.). (2004). Higher Education in a Changing Environment. Internationalisation of Higher Education Policy in Europe. Bonn: Lemmens, . ISBN 3-932306-55-4, 8-12.

Welch, A. R., and Denman, B. D. (1997). Internationalisation of Higher Education: Retrospect and Prospect", Forum of Education, 52(1), 14-29.

Zolfaghari, A., Sabran, M. S., Zolfaghari, A. (2009). Internationalization of higher education: Challenges, strategies, policies and programs. U.S.- China Education Review, 6(5), 1-9.

\begin{tabular}{l} 
JOLITA GREBLIKAITÉ \\
\hline PhD Social Sciences \\
Aleksandras Stulginskis \\
University \\
Address \\
Universiteto str. 10, LT-53361, \\
Kaunas distr., Lithuania \\
Tel. +37061644615 \\
E-mail: jolita19@gmail.com
\end{tabular}

\section{JURGITA BARYNIENÉ \\ PhD in Social Sciences (Business and Administration), Lecturer}

Kaunas University of Technology Faculty of Social Sciences, Arts and Humanities Institute of Europe

Address

A.Mickevičiaus st. 37, LT-44244, Kaunas, Lithuania

E-mail: jurgita.baryniene@ktu.lt
ŽIVILĖ PAUŽAITĖ

Lecturer

Kaunas University of Technology Faculty of Social Sciences, Arts and Humanities Institute of Europe

Address

A.Mickevičiaus st. 37, LT-44244,

Kaunas, Lithuania

Tel. +37068669923

E-mail: zivile.pauzaite@ktu.lt

\section{About the authors}

